\title{
in Science
}

through time and space

\author{
Жамият ва инновациялар - \\ Общество и инновации - \\ Society and innovations \\ Journal home page: \\ https://inscience.uz/index.php/socinov/index
}

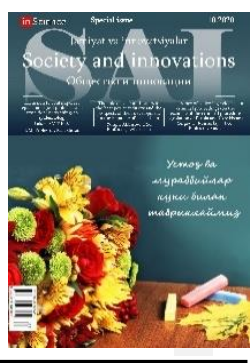

Perceived barriers for youth entrepreneurship and a possible solution: the case of Uzbekistan

\section{Yulia PARAMONOVA ${ }^{1}$}

Management Development Institute of Singapore (MDIS)

\section{ARTICLE INFO \\ Article history: \\ Received September 2020 \\ Received in revised form 15 \\ September 2020 \\ Accepted 25 September \\ 2020 \\ Available online \\ 1 October 2020}

\section{Keywords:}

Students' entrepreneurial intent

Entrepreneurial ventures

Crowdfunding

Access to finance

Social networking

Self-confidence.

\begin{abstract}
This paper analyses the main perceived barriers to starting a company on the example of university students and alumni in Uzbekistan. On the basis of previous studies by foreign authors the main barriers faced by entrepreneurs including young entrepreneurs were identified. Based on the studied literature and the methodology used in prior researches the author created an online questionnaire using multi-choice questions divided into several sectors. As a possible solution to minimize the consequences of the perceived barriers the respondents were asked to consider their willingness to use crowdfunding platforms to raise funds for their own projects, as well as to finance projects of other young entrepreneurs. The results of the regression model and statistical data made it possible to draw conclusions that legislators can take into account in the framework of the ongoing policy of supporting young entrepreneurship in Uzbekistan.

2181-1415/C 2020 in Science LLC.

This is an open access article under the Attribution 4.0 International (CC BY 4.0) license (https://creativecommons.org/licenses/by/4.0/deed.ru)
\end{abstract}

\section{Ёшлар тадбиркорлигининг тўсиқлари ва уларни хал қилишнинг мумкин бўлган йўллари: Ўзбекистон мисолида}

\author{
Калит сўзлар: \\ Талабаларнинг \\ ишбилармонлик нияти \\ Тадбиркорлик фаолияти \\ Краудфандинг \\ Молия \\ Ижтимоий тармоқ \\ Ўзига ишонч.
}

\begin{abstract}
АННОТАЦИЯ
Ушбу мақола бизнесни бошлашдаги асосий тўсиқларни Ўзбекистондаги олий ўқув юртлари талабалари ва битирувчилари мисолида тахлил қилади. Хорижий хамкасбларнинг аввалги тадқиқотлари асосида тадбиркорлар, шу жумладан бутун дунё бўйлаб ёш тадбиркорлар дуч келадиган асосий тўсиқлар аниқланди. Ўрганилган адабиётлар ва қўлланилган методика асосида муаллиф бир нечта сохаларга бўлинган холда кўп
\end{abstract}

\footnotetext{
${ }^{1}$ Senior Lecturer, Management Development Institute of Singapore (MDIS), Tashkent, Uzbekistan e-mail: yv.paramonova@gmail.com
} 
ўзгарувчан саволлардан фойдаланган холда онлайн анкета тузди. Тақдим этилган тўсиқлар оқибатларини минималлаштиришнинг мумкин бўлган эчими сифатида, респондентлардан ўз лойихаларига маблаг ъйиғиш, шунингдек бошқа ёш тадбиркорларнинг лойихаларини молиялаштириш учун краудфандинг платформаларидан фойдаланишга тайёрлигини кўриб чиқишни сўрашди. Регрессия модели ва статистик маълумотлар натижалари қонун чиқарувчилар Ўзбекистонда олиб борилаётган ёш тадбиркорликни қўллаб-қувватлаш сиёсати доирасида хисобга олиши мумкин бўлган хулосалар чиқаришга имкон берди.

\section{Предполагаемые препятствия для молодежного предпринимательства и возможное решение: на примере Узбекистана}

\author{
Ключевые слова: \\ Предпринимательские \\ намерения студентов \\ Предпринимательские \\ предприятия \\ Краудфандинг \\ Доступ к финансам \\ Социальные сети \\ Уверенность в себе.
}

\begin{abstract}
АННОТАЦИЯ
Данная статья анализирует основные барьеры на пути начала предпринимательской деятельности на примере студентов и выпускников ВУЗов Узбекистана. На основе ранее сделанных исследований зарубежных коллег были определны основные барьеры, с которыми сталкиваются предприниматели, в том числе и молодые предприниматели по всему миру. На основании изученной литературы и используемой методолгии автором был составлен онлайн опросник с использованием многовариантными вопросами, разделенный на несколько секторов. В качестве возможного решения для минимизации последствий предпоалагаемых барьеров респондентам было предложено рассмотреть готовность использования краудфандинговых платформ с целью сбора средств собственных проектов, а также финансирования проектов других молодых предпринимателей. Результаты регрессионной модели и статистических данных позволили сделать выводы, которые законодатели смогут учесть в рамках проводимой политики поддержки молодого предпринимательства в Узбекистане.
\end{abstract}

\section{INTRODUCTION}

Since Uzbekistan has embarked on ambitious reforms to foster innovation and entrepreneurship various new initiatives have been implemented. The evidence for these reforms taking strong shape can be the World Bank's Doing Business report where Uzbekistan has significantly improved its positioning to 69 and is included in the list of 20 most reforming states for 2020 (Doing Business, 2020). Economists and researchers around the world have identified innovative or technological entrepreneurial ventures to play major role in driving economic growth and development in emerging economies. The 
ultimate importance of new entrepreneurial developments cannot be over-emphasized. In the current times of global economic downturn entrepreneurial activity and that with innovative business models in particular could significantly stimulate consumption by creating more sustainable product offerings with lower costs and/or increased efficiency. In addition to that, entrepreneurial ventures provide jobs and reduce unemployment as well as generate taxes, which are then directed towards urgent societal needs.

Literature on youth entrepreneurship and its impact on a country's economic performance is very limited (Jena, R. 2020; Cieslik, J. 2016; Geldhof, J. et al, 2014), however young entrepreneurs are known to be more creative, possess wider knowledge and command of IT and have ability in multicultural networking. In addition to that, due to lack of family commitments they are much more prone to take risky decisions which entrepreneurial activities often imply (EC Report, 2016). Youth entrepreneurial ventures create new demands, tackle persistent problems with new technologies thus acting as a source of innovative solutions and in general are faster to adapt to ever more globalized markets.

\section{STATEMENT OF A PROBLEM}

With all the obvious benefits described above the development of youth entrepreneurial ventures in Uzbekistan remains relatively low. Identifying the major barriers to entry thus is of great importance together with finding proper strategies for minimizing and offsetting their negative impact. The research aims to understand if students and fresh graduates in Uzbekistan are aiming for self-employment after graduation and identify which of the most commonly perceived barriers of institutional and psychological character pose greatest challenge for them in doing so. As access to finance together with psychological barriers such as lack of self-belief and lack of social networking remain persistent challenges faced by young entrepreneurs (Taormina and Lao, 2007; Sandhu et al, 2010) crowd funding platforms might be suggested as a plausible solution in stimulating entrepreneurial activities in Uzbekistan. Hence the research objective was formulated as follows:

- to examine which of the perceived barriers (lack of finance, lack of selfconfidence, lack of prior experience, and lack of social networking/partners with knowledge and skills) have the highest impact on students' intentions to start a company.

- to investigate whether students and fresh graduates are willing to utilize crowd funding platforms to raise funds for their companies as well as to donate money to startup initiatives of others

\section{LITERATURE REVIEW}

The authors from the institutional school of thought have cited barriers such as lack of resources and lack of government assistance as some of the most persistent barriers for young entrepreneurs. For example, numerous prior research works have identified that one of the major challenges that young entrepreneurs face in their path to start a company is a limited access to finance (Clauss T. et al., 2018; Zhang and Chen, 2018, Bageri, A. et al. 2019). Evidence from emerging economies suggests that access to finance and ability to raise funds are still perceived by the entrepreneurs themselves as the most hindering factors on the path of launching and running a startup. For example, notwithstanding a 
substantial growth in new start up ventures, 61\% of Iranian entrepreneurs identified availability of finance as the most critical factor determining success of their startup undertakings (Saryazdi et al., 2018). Young entrepreneurs from 43 countries who took part in online and offline dialogues as part of the Road to Lima 2015 activities have also cited access to funding, education and trainings, better infrastructure, and networking opportunities as the main challenges on the path to start their own business (Viguria L, 2015).

Aside from institutional or external barriers some process-driven theories have emerged (Wang et al., 2001; Scott and Twomey, 2001), which have elaborated on the relationship between self-confidence and other variables as having an impact on ultimate decision to become an entrepreneur (Robertson et al., 2003). Lack of social networking is another barrier that many aspiring entrepreneurs face (Taormina and Lao, 2007; Luo, 1997). These authors in their postal surveys have employed the multiple-choice questions, both closed and open-ended, with an extensive number of barriers included in the survey. Their findings are consistent with prior works that indicate access to finance and adequate government support as major prerequisite for entrepreneurial intent. Other barriers identified include lack of confidence and entrepreneurial venturing being too risky which refers to a psychological theory of entrepreneurial intent (Robertson et al., 2003). Sandhu et al. in their study of Malaysian students' entrepreneurial inclinations and barriers have identified that factors of non-availability of funds and lack of social networking had the highest loading in the factor analysis with 0.607 and 0.550 respectively. These two barriers together with the embarrassment from failure were identified to pose the greatest challenge for students in their inclinations to start a business.

Crowdfunding came as an alternative form to traditional cumbersome tools of financing such as bank loans and venture capital investments with the first crowd funding website Artistshare.com launched in the U.S in 2001 (source). As an integral part of digital economy these technology-enabled platforms connect founders and investors as well as other members of the community and help build informal ties to produce invaluable highdensity resources (Parker, G. et al., 2016, Caridà, A. et al., 2017). A model of crowdfunding implies relatively small amounts of investments from different individuals to allow for independence from large institutional investors (Ordanini et al., 2011). These individual investors are motivated rather by non-financial factors such as intrinsic altruism, core values and ideas of an entrepreneurial project (Lehner, 2013) rather than focusing on purely financial objectives of the business plan as is typical for large investors (Belleflamme et al., 2014).

Many governments having realized the potential of these flexible digital platforms have promoted and encouraged creation of crowdfunding sources to foster diverse entrepreneurial activities. For example, South Korea government has legalized crowdfunding platforms in 2015 (Allison et al., 2015), while Russia has just recently enacted crowdfunding regulation starting from Jan 1, 2020. However, it mostly focuses on protecting investors rather than simplifying the process for startups and removing existing barriers. (https://www.crowdfundinsider.com/2019/10/153061-new-regulation-ofcrowdfunding-in-russia/). In India, although crowd funding itself is not a new phenomenon, it still is in pubescent stage, facing a lot of problems and no proper regulation. However, In 2014 Securities and Exchange Board of India (SEBI) proposed 
guidelines aimed at facilitating access to funds for start-ups and small-to-medium enterprises via crowd funding (https://www.investindia.gov.in/team-indiablogs/crowdfunding-india-0)

In the case of Uzbekistan access to finance through formal banking and financial institutions has been confined primarily to established firms with a rather proven business model and successful financial performance. Overall, the process of getting credit is extremely lengthy and bureaucratic whereby firms are required to produce and fill out myriads of forms and references, present a company's balance sheet, proof of assets and other forms of equity. In this regard, crowd funding is the mechanism that offers entrepreneurs a relatively easy way to raising a seed capital from a broad range of population, including institutional and individual investors, the so-called peer investors (Clauss et al., 2018). Moreover, crowdfunding platforms operate as open networks effectively fostering continuous collaboration and ties among peer members, entrepreneurs and the crowd (Ketonen-Oksi, Jussila, \& Kärkkäinen, 2016). As a spill-over effect of these ties internal social capital that accrues through this collaboration reinforces the value-generating processes both on internal and external levels (Colombo et al, 2015). Aside from raising funds, launching projects through crowd funding avenues allows entrepreneurs to connect with potential target audience, test product concepts and create a buzz to raise product awareness in the market. (Gleasure, 2015). Attracting potential customers in the earliest stages of product development and activating informal ties with the audience is critical to assuring that the product of the crowdfunding initiative has a market fit (Fehrer J., Nenonen S., 2019). For example, Anderson (2014) has suggested that crowd funding avenues allow for the development of the so-called collective intelligence, whereby entrepreneurs gather invaluable feedback and expert opinion, or even gain access to creative customer insights generated from the crowd to further fine tune the product offering or the business model itself.

\section{METHODOLOGY}

This research employs both quantitative and qualitative approaches as both aim to enrich the research with a more profound knowledge about the perceived barriers to students' entrepreneurial activities as well as their willingness to employ crowdfunding platforms as a tool for raising funds for their potential startup. For this purpose, a multiplechoice survey has been designed by a researcher and tested on a group of 5 students to understand if the research aim is clear and questions are coherent with the research objectives. Cronbach Alpha test then was run on Stata software to confirm the questionnaire's reliability. A total of 102 students from local universities (the majority of respondents from MDIS and Webster universities located in Tashkent) have participated in the survey, which was distributed online via forms.office.com. Due to missing data in some of the answers the sample size totaled 97. The data was further used to develop a regression model using Stata software platform to examine the effects of perceived barriers on students' intent to start a company. The questionnaire was designed in three sections, the first covering demographic questions, the second section pertaining to student's entrepreneurial intent, the third section focused on perceived barriers and the final section covering crowd funding platform issues. Open-ended questions at the end of 
the survey have added a qualitative twist of students' unbiased perception related to perceived barriers for entrepreneurial undertakings.

\section{THE RESULTS}

The survey results have demonstrated that a staggering $64 \%$ of respondents are intending to start a company in the future, with $18 \%$ opting for a choice of having already tried and failed and 6\% - currently running their own companies. Absolute majority (61\%) of respondents have identified lack of financing as the main hindering factor to launch a startup while 'lack of partners with knowledge and experience' as well as 'lack of prior experience' cited as other two major challenges (21\% and 20\% respectively).

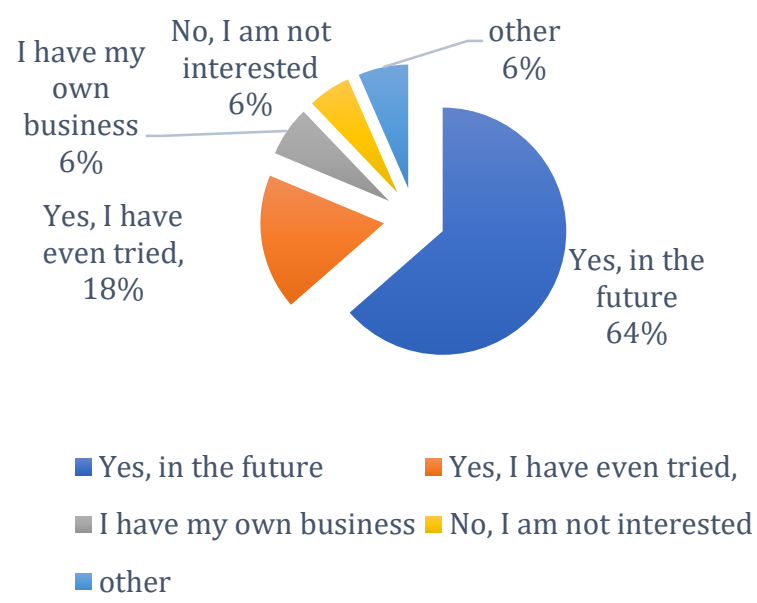

Q. Are you planning to start your own company?

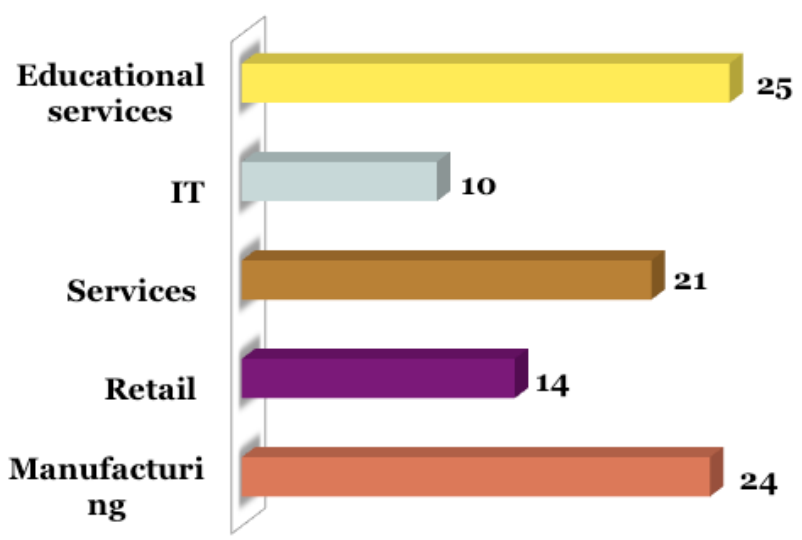

Q. Should you start a company what type of company that would be?

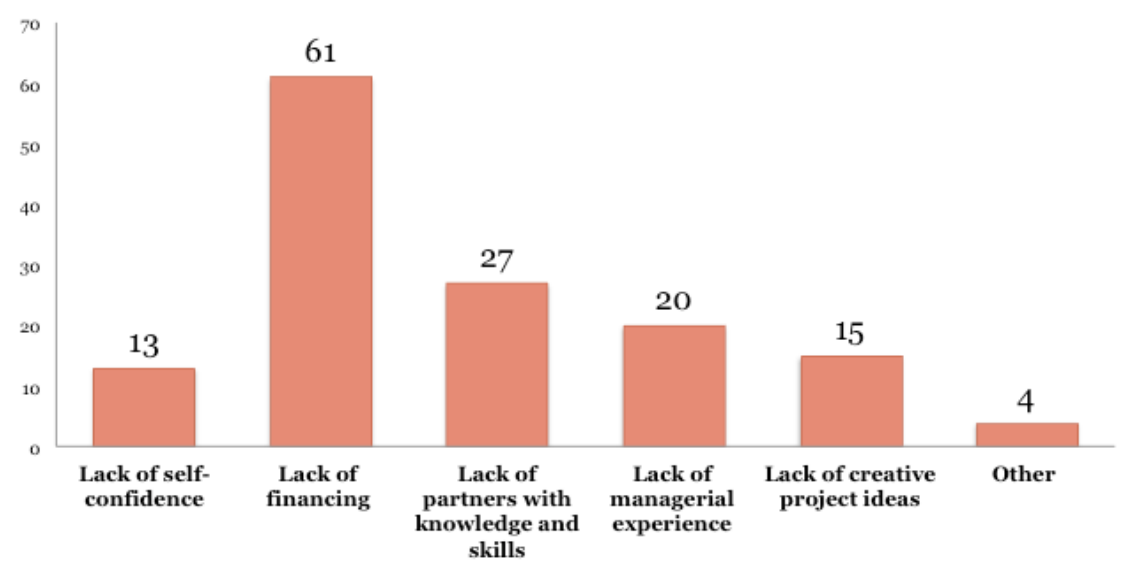


Q. What are the barriers that may stop you from starting your own company?

Table 1 Regression model for the three independent variable

- reg startacomp_1 lackoffinance_2 lackofconfidence_7 lackofexperience_4

\begin{tabular}{|c|c|c|c|c|c|c|}
\hline Source & SS & $d f$ & MS & Number of obs & $=$ & 98 \\
\hline & & & & $F(3,94)$ & $=$ & 7.83 \\
\hline Model & 12.8507138 & 3 & 4.28357127 & Prob $>F$ & $=$ & 0.0001 \\
\hline Residual & 51.3941841 & 94 & .54674664 & R-squared & $=$ & 0.2000 \\
\hline & & & & Adj R-squared & $=$ & 0.1745 \\
\hline Total & 64.244898 & 97 & .662318536 & Root MSE & $=$ & .73942 \\
\hline
\end{tabular}

\begin{tabular}{|c|c|c|c|c|c|c|}
\hline startacomp_1 & Coef. & Std. Err. & $\mathrm{t}$ & $P>|t|$ & [95\% Conf. & Interval] \\
\hline lackoffinance_2 & -.1847561 & .0760305 & -2.43 & 0.017 & -.3357165 & -.0337956 \\
\hline lackofconfidence_7 & -.2915378 & .1640136 & -1.78 & 0.079 & -.6171907 & .0341151 \\
\hline lackofexperience_4 & -.235297 & .1588089 & -1.48 & 0.142 & -.5506158 & .0800218 \\
\hline _cons & 4.866573 & .2961712 & 16.43 & 0.000 & 4.278518 & 5.454627 \\
\hline
\end{tabular}

Table 2 Regression model for one independent variable with the highest relation to

- reg startacomp_1 lackofconfidence_7

\begin{tabular}{|c|c|c|c|c|c|c|}
\hline Source & SS & $d f$ & MS & Number of obs & $=$ & 98 \\
\hline Model & 7.98754264 & 1 & 7.98754264 & Prob $>F$ & $=$ & 0.0004 \\
\hline Residual & 56.2573553 & 96 & .586014118 & R-squared & $=$ & 0.1243 \\
\hline & & & & Adj R-squared & $=$ & 0.1152 \\
\hline Total & 64.244898 & 97 & .662318536 & Root MSE & $=$ & .76552 \\
\hline
\end{tabular}

\begin{tabular}{|c|c|c|c|c|c|c|}
\hline startacomp_1 & Coef. & Std. Err. & $\mathrm{t}$ & $P>|t|$ & [95\% Conf. & Interval] \\
\hline lackofconfidence_7 & -.5030715 & .1362627 & -3.69 & 0.000 & -.7735509 & -.2325921 \\
\hline _cons & 4.192693 & .1902308 & 22.04 & 0.000 & 3.815088 & 4.570298 \\
\hline
\end{tabular}

The results of the regression analysis in Table 1 are indicating that although responses for 'lack of finance' greatly outnumbered responses for other variables 'starting a company' is more significantly related to two other perceived barriers 'lack of self-belief' and 'lack of prior experience', which are more psychological in nature as they refer to students' own perception of their abilities and skills. The other two options were not used in the regression as prior correlation analysis has revealed an insignificant correlation of these independent variables to the main variable. Overall these three perceived barriers explain c. $18 \%$ of variations of students' intent to start a company. The Table 2 model 
demonstrates the value for an individual variable 'lack of self-confidence' as having the strongest relation to the main variable of 'starting a company'. This variable alone is responsible for $11,5 \%$ of variations in students intent to start a company. The open-ended questions asked in the end of the survey to identify other barriers that young entrepreneurs face in their undertakings have revealed to the following. The most recurring answers pertained to high levels of bureaucracy and corruption, lack of support mechanisms from the government as well as inadequate business knowledge and skills on behalf of youngsters themselves. As we may see the first two perceived barriers are of institutional nature, while the latter is more psychological.

When asked about their awareness of global crowdfunding platforms respondents were quite unanimous in showing they have some knowledge of the large global platforms such as gofundme.com (46\%) and indiegogo.com (23\%). However, in relation to their willingness to use a similar local platform to raise funds for their own business respondents showed some hesitation with $25 \%$ answering they find it a great option and $41 \%$ willing to use the platform only very cautiously. The remaining $31 \%$ answered that they don't find it a good option for them. With regards their willingness to use the platform to 'donate' money for an interesting startup project 32 respondents chose an option 'yes, willingly', while other $32 \%$ were ready to donate money only if they personally new the entrepreneur/team behind the project. $9 \%$ of the respondents were not ready to donate and answered 'no way', while the remaining $24 \%$ of respondents who opted for 'no' as an answer where ready to reconsider the option in the future.

Referring to the amount the respondents were ready to donate to startup initiatives of others 33\% chose a bracket of $\$ 500$ and above with 17\% opting for $\$ 100-\$ 200$ range. Overall, based on the total responses received the average donation amount per individual was estimated at $\$ 237$. However, the global average donation amount per campaign is \$88, while that in developing countries being considerably lower ( $\$ 25$ per campaign in Russia), therefore it is probable that numbers have been manipulated due to a response bias. When setting these numbers against the average project cost of $\$ 25,000$ required by the respondents to start their own business it would take c. 1000 individual investors to fund it. For a project with a cost of $\$ 5,000-\$ 10,000$ it would take on average 300-400 individual investors to raise the required amount.

The above findings indicate the main areas of development that the government together with educational institutions has to focus on in their efforts to bolster entrepreneurial activities in Uzbekistan. The proposed solution of establishing crowd funding platforms that would also serve a purpose of crowdsourcing ideas, building networks and acquiring self-confidence while running a project campaign could be a sound option for policy makers to implement in the nearest future. The results are also demonstrating that students are ready to employ this mechanism both for funding their startups as well as for helping others raise money for their endeavors. The stimulation of entrepreneurship should be especially important for the economy on the brink of recessional trends amid Covid-19 pandemic and mounting pressures to build a more innovative and knowledge-driven economy. Youth entrepreneurship can lead the way in the development of novel and more efficient business models and create new jobs and opportunities. 


\section{References:}

1. Allison, T.H., Davis, B.C., Short, J.C., Webb, J.W., 2015. Crowdfunding in a prosocial microlending environment: examining the role of intrinsic versus extrinsic cues.

2. Bageri, A. et al., 2019 Crowdfunding motivations: A focus on donors' perspectives

3. Belleflamme, P. et al., 2015. The economics of crowdfunding platforms

4. Clauss T. et al, 2018 Entrepreneurial University: A stakeholder-based conceptualisation of the current state and an agenda for future research

5. Carida, A., et al, 2018 Business model design and value co-creation: looking for a new pattern

6. Clifford, E., 201616 Young and successful entrepreneurs who prove that age is nothing but a number https://www.lifehack.org/588440/16-young-and-successfulentrepreneurs-who-prove-that-age-is-nothing-but-a-number

7. Colombo, Franzoni, 2015 Internal social capital and the attraction of early contributions in crowdfunding https://journals.sagepub.com /doi/abs/10.1111/etap.12118

8. Fehrer JA, Neronen S., 2019 Crowdfunding networks: Structure, dynamics and critical capabilities

9. Tadjibaeva D., 2019 Small and medium-sized enterprise finance in Uzbekistan: challenges and opportunities, ADB working paper, 2019

10. Kritikos A., 2014 Entrepreneurs and their impact on jobs and economic growth

11. Cieslik J., 2016 Entrepreneurship in emerging economies

12. EC Report, 2016 Young and Innovative: how to help young entrepreneurs to be more innovative (https://ec.europa.eu/easme/sites/easme-site/files/713810 younginnovative-design option paper.pdf).

13. Geldhof J. et al, 2014 Entrepreneurship in young adults: Initial finding from the young entrepreneurs study

14. Jena R., 2020 Measuring the impact of business management Student's attitude towards entrepreneurship education on entrepreneurial intention: A case study

15. Lehner, O.M., 2013 Crowdfunding social ventures: a model and research agenda. Venture Capital: An International Journal of Entrepreneurial Finance 15 (4), 289-311.

16. 14 most influential young entrepreneurs in India who are making it big in 2020 https://www.innfinity.in/limitless/young-entrepreneurs-in-india/

17. Ordanini, A., et al. 2011. Crowd-funding: transforming customers into investors through innovative service platform

18. Parker G. et al., 2016 Platform revolution: how networked markets are transforming the economy - and how to make them work for you

19. Robertson et al., 2003 Barriers to stat-up and their effect on aspirant entrepreneurs

20. Sandhu, Manjit Singh et al., 2010 Entrepreneurship barriers and entrepreneurial inclination among Malaysian postgraduate students

21. Saryadzi et al., 2018 Providing a business model for crowdfunding in Iran

22. Surabhi K., 2019 Top 10 Young Entrepreneurs of India (https://www.marketingmind.in/top-10-young-entrepreneurs-of-india/)

23. Taormina, RJ, Lao, SKM 2007 Measuring Chinese entrepreneurial motivation 
24. Viguria L., 2015 Why Young entrepreneurs are so important (https://www.weforum.org/agenda/2015/10/why-young-entrepreneurs-are-soimportant/)

25. Zhang, H., Chen, W., 2018b. Crowdfunding technological innovations: interaction between consumer benefits and rewards. Technovation 